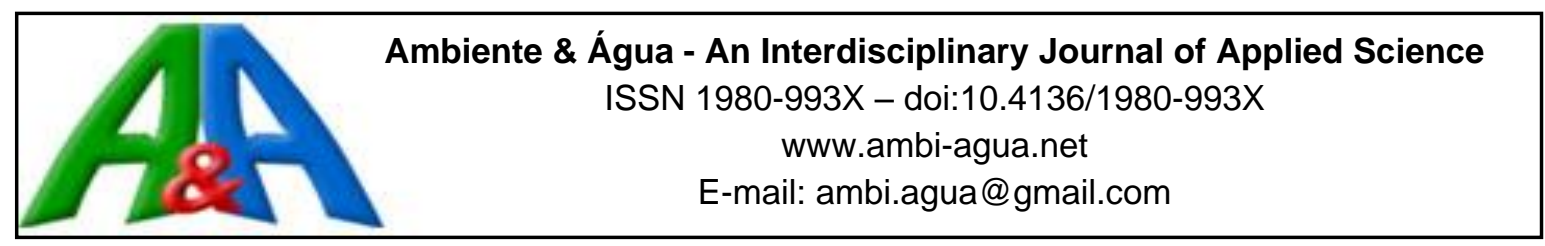

\title{
Numerical Simulation of Debris Flows of the Catastrophic Event of February 2019 in Mirave - Peru
}

\author{
ARTICLES doi:10.4136/ambi-agua.2437
}

Received: 04 Jul. 2019; Accepted: 23 Sep. 2019

\begin{abstract}
Alexandre Almeida Del Savio ${ }^{1 *}$ iD; Samuel Ismael Quisca Astocahuana ${ }^{2}$ iD; Leonardo Franco Castillo Navarro ${ }^{3}$ iD

${ }^{1}$ Carrera de Ingenier a Civil. Ingeniería Civil. Universidad de Lima, Avenida Javier Prado, n 4600 , CEP: 15023, Santiago de Surco, Lima, Peru.

${ }^{2}$ Carrera de Ingenier a Civil. Ingeniería Civil. Universidad Nacional Mayor de San Marcos, Calle Germán Amézaga, n 375, CEP: 15081, Ciudad Universitaria, Lima, Peru. E-mail: squisca@gmail.com

${ }^{3}$ Facultad de Ingeniería Civil. Universidad Nacional de Ingeniería, Avenida Túpac Amaru, n² 210, CEP: 15333, Rímac, Lima, Peru. E-mail: leonardocastillo@uni.edu.pe

*Corresponding author. E-mail: delsavio@gmail.com
\end{abstract}

\begin{abstract}
Debris flows are geophysical phenomena, caused by torrential rain, which occur in mountainous areas, characterized by the detachment of slope and riverbed materials and their consequent dislodge through watersheds and streams. Debris flows usually carry sludge, water and rocks, and can destroy everything in their path. On February $8^{\text {th }}, 2019$, an event of this type occurred and destroyed Mirave's community in Peru, which was located in the areas of transport and deposition of debris flows. This research presents the modeling and numerical simulation to reproduce the transport and deposition processes of the debris flow that occurred in Mirave. The initiation process of the debris flow in streams was represented by hydrographs obtained from the estimated rain runoff volumes and solid materials found at each evaluated micro watershed. The numerical simulation results show acceptable results in terms of reproduction of the extension of the affectation and deposition areas of solids related to the studied debris flow. The resulting velocity field shows an adequate representation of the erosion zones observed in the area. The model used for evaluating the disaster risk by debris flows can predict and delimit, with acceptable accuracy, the potentially dangerous areas for a mudslide event. The application of the proposed methodology for assessing the disaster risk due to debris flows at watersheds and streams is useful to understand the extent of debris flow affectation during extreme weather events, as well as to develop emergency plans, and to formulate disaster management policies in Peru or in other countries with similar conditions.
\end{abstract}

Keywords: debris flow, hazard assessment, hydrographs, hyperconcentrated flow, mud flow.

\section{Simulação Numérica dos Fluxos de Detritos do Evento Catastrófico de Fevereiro de 2019 em Mirave - Peru}

\section{RESUMO}

Os fluxos de detritos são fenômenos geofísicos provocados por chuvas torrenciais, que ocorrem em áreas montanhosas, e se caracterizam pelo desprendimento de materiais de declives e de leitos de rios e seu consequente arraste água abaixo através de bacias e córregos. Os fluxos 
de detritos carregam consigo, em geral, lodo, água e rochas, e podem destruir tudo o que está em seu caminho. No dia 8 de fevereiro de 2019 ocorreu um evento deste tipo que destruiu a comunidade de Mirave, no Peru, que estava localizada nas áreas de trânsito e deposição dos fluxos de detritos. Esta pesquisa apresenta a modelagem e simulação numérica para reproduzir os processos de iniciação e deposição de fluxos de detritos ocorrido em Mirave. O processo de iniciação dos fluxos de detritos nos desfiladeiros foi representado por hidrogramas obtidos a partir dos volumes estimados de escoamento de água da chuva e materiais sólidos encontrados em cada microbacia avaliada. Os resultados das simulações numéricas mostram resultados aceitáveis em termos de reprodução da extensão do impacto nas áreas de deposição de sólidos relacionados ao fluxo de detritos estudado. O campo de velocidades resultantes mostra uma adequada representação das zonas de erosão observadas in loco. $\mathrm{O}$ modelo usado para a avaliação do risco de desastres por fluxos de detritos é capaz de prever e delimitar, com uma aproximação aceitável, as áreas potencialmente perigosas para um evento de deslizamento de terra com um período de retorno determinado. A aplicação da metodologia proposta para avaliação do risco de desastres devido aos fluxos de detritos, a bacias e riachos, é útil para entender a extensão dos impactos gerados pelos fluxos de detritos durante eventos climáticos extremos, bem como para o desenvolvimento de planos de emergência e formulação de políticas de gestão de desastres no Peru.

Palavras-chave: avaliação de risco, fluxo de detritos, fluxo de lama, fluxo hiperconcentrado, hidrogramas.

\section{INTRODUCTION}

Debris flows are geophysical phenomena, caused by torrential rain, which occur in mountainous areas, characterized by the detachment of slope- and riverbed materials and their consequent dislodge through watersheds and streams. Debris flows usually carry sludge, water and rocks, and can destroy everything in their path.

Disasters caused by debris flows have occurred in different parts of the world, mainly in the alluvial cones of urban and rural areas, as reported by Gerasimov and Zvonkova (1974), Campbell (1975), Schuster et al. (2002), Li (2004), Mizuyama and Egashira (2010). In Peru, debris flows are among the three most important natural disasters.

The year 2019 started with extreme climatic variations in Peru, causing the activation of dry streams in different regions of the country. This has led to the occurrence of hyperconcentrated flows and debris flows in usually dry watersheds, damaging populations and resulting in the loss of human lives.

According to the Complementary Report 01 of INDECI (2019), on February $8^{\text {th }}, 2019$ at approximately $15 \mathrm{~h} 30$, there was a debris flow as a result of intense rains registered in the area, affecting the Mirave Town Center, in the district of Ilabaya, Jorge Basadre province, Tacna Region. That debris flow would have had a return period of 92 years, considering a similar debris flow occurred in 1927. Therefore, a 100-year return period was considered for the numerical simulations of debris flow event of February 2019.

Mirave's watershed is made up of four main watersheds, whose streams have a high slope, are dry and without vegetation. They are eventually activated during the occurrence of strong or extraordinary rainfall. The populated center of Mirave occupies the entire channel main gulch and its cone exit section, exposing them to the occurrence of debris flows of different magnitudes.

The research performed numerical modeling and simulation to reproduce the transport and deposition processes of the debris flow that occurred on February $8^{\text {th }}, 2019$. The initiation process of the debris flow in the streams was represented by hydrograms calculated from estimated volumes of rain runoff and solid materials found in the studied watershed. 
For the modeling and simulation of the debris flow of 2019, the existence of sediment retention dikes in the main channel and its tributaries of Mirave's watershed, which were built before the occurrence of the debris flow of 2015, were considered. The dikes worked effectively, reducing the damage caused by the debris flow of 2015. This conferred a false security to Mirave's populated center, which resulted in the omission of the cleaning process to restore the storage capacity of the sediment retention dikes that had been filled during the debris flow of 2015. The transport of the debris flow of 2019 passed over the clogged dikes, without suffering the attenuating effect of solid retention and, on the contrary, eroded the foundation of the levees and generated the collapse of part of them as well. A collapse of part of the dykes and their dissipating pools, which was caused mainly by erosion below their foundation, was observed on site and reached a maximum depth of $3 \mathrm{~m}$ on average with the presence of regressive erosion in part of them. Any event of future debris flow of medium or low magnitude could produce the imminent collapse of sediment retention dikes.

For the modeling and numerical simulations of the debris flow that occurred in February 2019, the commercial software FLO-2D was selected, which uses the rheological model of quadratic stress proposed by O'Brien et al. (1993). This software has been used in numerous studies of mudflows in different parts of the world, with acceptable results for engineering purposes.

This research presents modeling and numerical simulation to reproduce the debris flow that occurred in 2019, and which destroyed the population center of Mirave, Peru. The procedure of modeling and simulation of debris flows applied to the case of Mirave's watershed is part of a methodology for evaluating the disaster risk by debris flows, applicable to streams found in Peru.

\section{MATERIAL AND METHODS}

\subsection{Theoretical aspects of debris flows}

The initiation process of debris flows can be caused by high intensity rainfall, which erodes the surface of mountain slopes or the material deposited in the channels of streams. According to Takahashi (1991), they can also be initiated as a result of landslides on slopes or by the breakage of dams. The transport process of the debris flow takes place in the main stream or river channel, where the biphasic liquid and solid particles mix moves downstream through the channel, with high erosion and abrasion power, and high impact force. Finally, in the deposition process, the debris flow is deposited in a flatter area, called the "dejection cone", where the interstitial fluid continues to flow or drain over the deposited body. The debris flows are a biphasic mixture of liquid with extended granulometry solids, which, extended according to the duration or continuity of the rains, concentrations of solids, and the size of solid particles, flow in the following types of flow: hyperconcentrated flow, mud flow and debris flow.

Numerous numerical models have been developed to predict the devastating effects produced by debris flows for transport and deposition of the debris-flow processes. Phillips and Davies (1989) pointed out that problematic debris flows are invariably pulsating and nonstationary phenomena, and stressed the need to develop a model that was closer to reality and of practical value to predict debris flows. As reported by Aguirre-Pe et al. (1995) and Quisca (2002), numerous authors have proposed simplified numerical models for debris flows, from uniform permanent flows to flows gradually varied in space. Other authors use the well-known Saint Venant equations for shallow waters in the numerical modeling of debris flows, where they consider the non-permanent behavior of the flow. On the other hand, authors such as Laigle and Coussot (1997), Brufau et al. (2000), and Quisca (2002), proposed or used different governing equations from the Saint Venant equation, considering the non-permanent flow and effects closer to the real events of debris flows. Along these lines, the numerical models of transport processes and deposition of debris flows are currently being developed. 
The numerical models for physical processes of debris-flow initiation are very scarce, and there are few attempts to numerically simulate all the processes from the initiation to the subsequent transport and deposition of the debris flow. According to Shen et al. (2018), the integrated numerical simulation of the three processes of debris flows remains a challenge to be solved. In addition, it indicates that instead of the initiation process, a predefined empirical hydrograph is used, created based on the estimated volumes of rain runoff and solid source materials, to initiate debris flow. This procedure involves great uncertainties regarding location, times and volumes of the beginning of debris flows; however, using field evaluation and the characteristics of debris flows that have occurred in the watersheds, uncertainties can be reduced, and valid predictions can be obtained for practical purposes.

Nowadays, there are numerous numerical models developed for debris flows, applicable to the different rheologies of the biphasic mixture. O'Brien et al. (1993) developed the wellknown FLO-2D program, used for hyperconcentrated flows and mud flows. Hungr (1995), and Hungr and McDougall (2009) developed the DAN and DAN-3D programs, used for plastic flows, friction flows, Newtonian laminar flows, turbulent flows, Bingham flows, Coulomb viscous flows, and Voellmy fluid rheological behavior. Bartelt et al. $(2013 ; 2017)$ developed the RAMMS program for numerical modeling of snow avalanches, debris flows, rockfalls and rock avalanches. The rheological model used by RAMMS for debris flows is the Voellmy friction fluid model, which divides the friction resistance into two parts: a dry Coulomb-type friction, and a resistance to the square of the velocity or viscous-turbulent friction. Shen et al. (2018) presented the integrated numerical model, EDDA 2.0, to simulate the entire process of initiation of debris flow, movement dragging, deposition, and ownership changes; however, the authors indicate that the rheological models used for hyperconcentrated flow and the fully developed debris flow need further study.

\subsection{Area of study}

The area of study is located in Mirave's watershed, which is a minor hydrographic unit within Locumba's watershed (See Figure 1). Mirave's watershed has a total area of $35.81 \mathrm{~km}^{2}$. The hydrographic system consists of a drainage network of secondary rivers and minor streams. The maximum altitude in the watershed is 2268 meters above sea level, while the minimum altitude is 1102 meters above sea level. It has a channel length of $12.47 \mathrm{~km}$ and average slope of the main channel of $8.8 \%$. The town of Mirave is located at an average altitude of 1117 meters above sea level and its urban development occupies the entire channel of the outlet section of the main stream of Mirave's watershed, as well as of the entire natural extension of the dejection cone, which constitutes a very high risk in the event of mudslides, as shown in Figure 2. The debris flow that occurred on February $8^{\text {th }}, 2019$ devastated Mirave's center (See Figure 3). For study purpose3, Mirave's watershed has been divided into four micro watersheds, which will be referred to hereinafter: Mirave 1 Stream, Mirave 2 Stream, Mirave 3 Stream and Mirave 4 Stream, as shown in Figure 1.

\subsection{Estimated flow rates peaks of debris flow in the four streams of Mirave's watershed}

To estimate the production of sediments in each of the micro watersheds of the main Mirave's watershed, the Zemljic-Gavrilovic methodology with the variations of Milanesi et al. (2015) was used to quantify the erosive process according to the morphological characteristics, vegetation and land use, distribution of rainfall and temperature. The values of the average annual sediment volumes produced by erosion were estimated and transported to the outlet section in each micro watershed of the streams, considering the normal hydrological conditions. For extreme hydrological conditions, the average annual volumes of solids produced by erosion and arriving at the outlet of the four streams will be several times greater than the values estimated under normal hydrological conditions. 

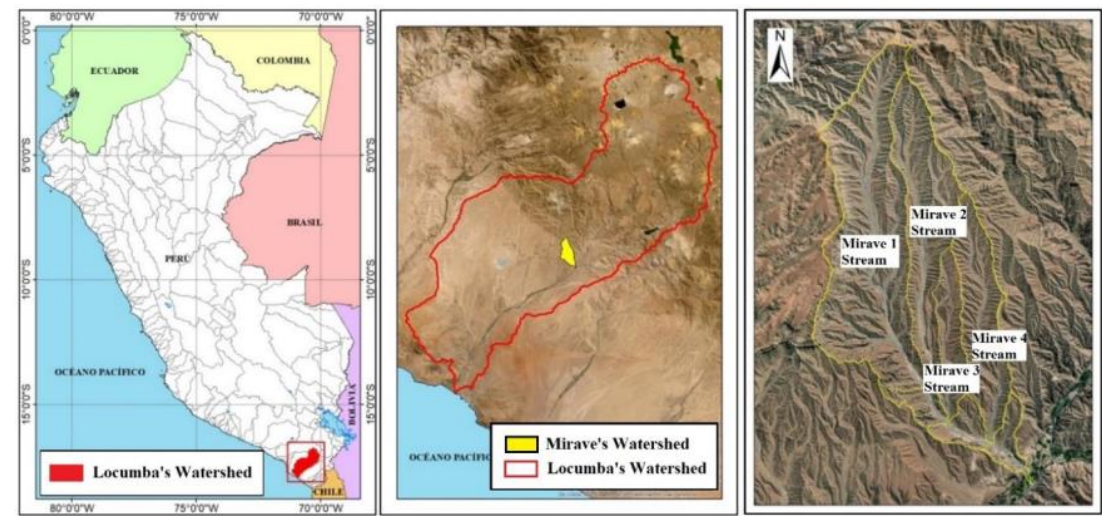

Figure 1. Mirave's watershed location and its four main streams.

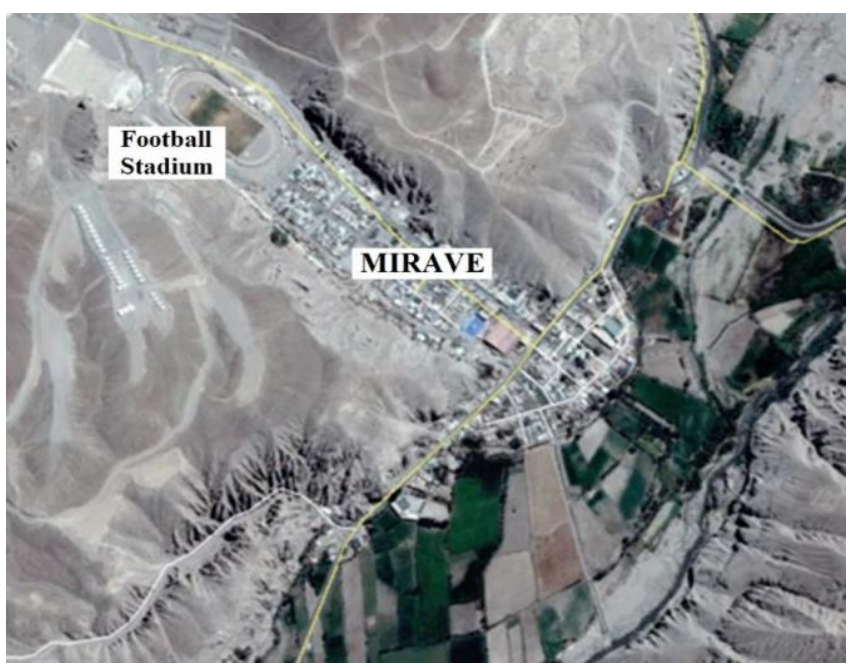

Figure 2. The location of Mirave's population center occupies the entire channel of the outlet mouth of the main stream, and the area of the dejection cone of Mirave's watershed, an area that belongs to the flow path and deposition area of debris flows. Source: Google Earth (2016).

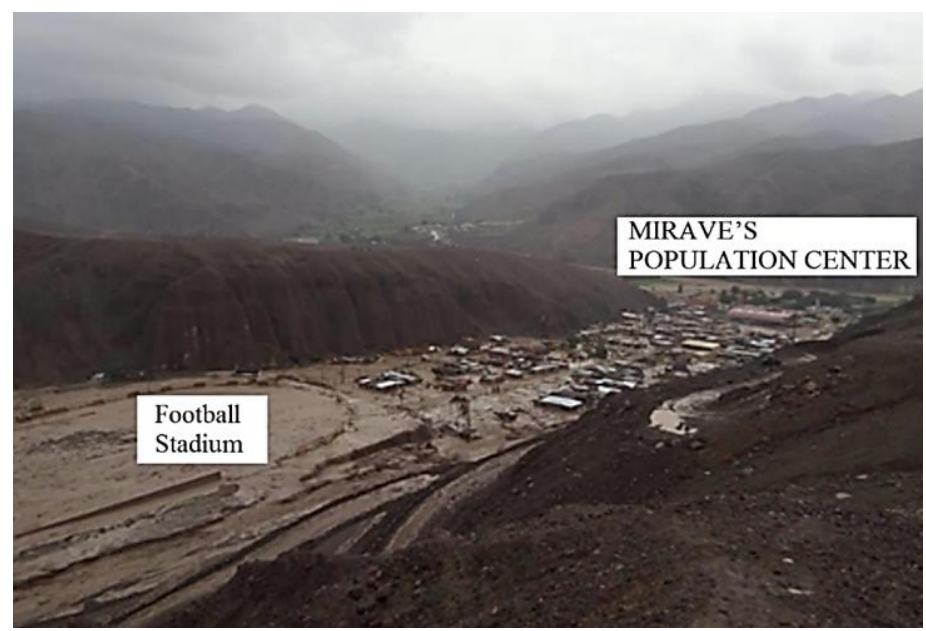

Figure 3. A debris flow occurred on February $8^{\text {th }}, 2019$ in Mirave's watershed and devastated Mirave's town center, which occupies the entire channel of the outlet mouth of the main stream and the area of the dewatering cone of Mirave's watershed. Source: Diario Correo (2019). 
Rickenmann (1999) establishes the need to determine the probability of occurrence or nonoccurrence of debris flows in watersheds of streams and torrents, and for this requires the verification of the existence of steep slopes, adequate availability of detrital materials and ease of mobilization, as well as the sufficiency of water to trigger the flow of mudslides. Currently, there are numerous empirical formulas to estimate the volume of detrital materials that will erode and incorporate debris flow, based on morphometric parameters of the stream watershed. However, a geomorphological field evaluation of the detrital material that is likely to be incorporated into the debris flow is recommended, in order to obtain a more reliable estimate of a possible debris flow volume.

On the other hand, the pulsating characteristics of hyperconcentrated flows and debris flows are known, Phillips and Davies (1989), and are associated with the hydrological response of high-intensity and short-duration rains. In this sense, the procedure of constructing a debris flow event hydrograph from liquid hydrograph is reasonable. The pulsating characteristic of the debris flow in the streams of Mirave's watershed supports the conjecture that a debris flow will consist of one to two waves of debris flow at a minimum.

From the field inspection of the watershed and the analogy of the events of debris flows of similar watersheds of the country, a classification and characterization of debris flows was carried out in the four streams of Mirave's watershed, which are recorded in Table 1 and 2.

These estimated rheological parameters are congruent with the empirical values given by Rickenmann: from $1600 \mathrm{~kg} / \mathrm{m}^{3}$ to $2000 \mathrm{~kg} / \mathrm{m}^{3}$ for mud flow, and from $1900 \mathrm{~kg} / \mathrm{m}^{3}$ to 2300 $\mathrm{kg} / \mathrm{m}^{3}$ for granular debris flow.

For the estimates of solid volumetric concentration (stones, gravel, sands and fines), the formulas proposed by Takahashi (1991) were applied, assuming a stable flow in movement (Equation 1):

Table 1. Classification and characteristics of debris flows in Mirave 1 and Mirave 2 Streams.

\begin{tabular}{|c|c|c|}
\hline $\begin{array}{l}\text { Classification and } \\
\text { characteristics of debris flows }\end{array}$ & Mirave 1 Stream & Mirave 2 Stream \\
\hline Morphologically & Debris flows in riverbed & Debris flows in riverbed \\
\hline Geological structure & $\begin{array}{l}\text { Erosion of residual soils and rock } \\
\text { weathering }\end{array}$ & $\begin{array}{l}\text { Erosion of residual soils and rock } \\
\text { weathering }\end{array}$ \\
\hline Mechanism of occurrence & $\begin{array}{l}\text { Landslides and accumulation of } \\
\text { material in the riverbed }\end{array}$ & $\begin{array}{l}\text { Landslides and accumulation of } \\
\text { material in the riverbed }\end{array}$ \\
\hline Transportation mechanism & Highly non-stationary and pulsating & Highly non-stationary and pulsating \\
\hline Effect on the river bed & Erosive & Erosive \\
\hline Volume of the event & $\begin{array}{l}\text { High } \\
\text { (greater than } 100,000 \mathrm{~m}^{3} \text { ) }\end{array}$ & $\begin{array}{l}\text { High } \\
\text { (greater than } 100,000 \mathrm{~m}^{3} \text { ) }\end{array}$ \\
\hline Recurrence of the event & $\begin{array}{l}\text { Low } \\
\text { (Frequency more than } 10 \text { years) }\end{array}$ & $\begin{array}{l}\text { Low } \\
\text { (Frequency more than } 10 \text { years) }\end{array}$ \\
\hline Type of flow & $\begin{array}{l}\text { Between mud flows and } \\
\text { debris flows }\end{array}$ & $\begin{array}{l}\text { Between mud flows and debris } \\
\text { flows }\end{array}$ \\
\hline Flow characteristic & Pulsating, several waves & Pulsating, several waves \\
\hline Granulometry & $\begin{array}{l}\text { Coarse granulometry (pebbles, } \\
\text { gravel, sands and fines) }\end{array}$ & $\begin{array}{l}\text { Coarse granulometry (pebbles, } \\
\text { gravel, sands and fines) }\end{array}$ \\
\hline Density & $1900 \mathrm{~kg} / \mathrm{m}^{3}$ & $1900 \mathrm{~kg} / \mathrm{m}^{3}$ \\
\hline Viscosity & $\begin{array}{l}\text { High viscosity } \\
\text { (higher than } 1000 \text { water viscosity) }\end{array}$ & $\begin{array}{l}\text { High viscosity } \\
\text { (higher than } 1000 \text { water viscosity) }\end{array}$ \\
\hline Speed & Medium & Medium \\
\hline
\end{tabular}


Table 2. Classification and characteristics of debris flows in Mirave 3 and Mirave 4 Streams.

\begin{tabular}{|c|c|c|}
\hline $\begin{array}{l}\text { Classification and characteristics } \\
\text { of the debris flows }\end{array}$ & Mirave 3 Stream & Mirave 4 Stream \\
\hline Morphologically & Debris flows in riverbed & Debris flows in riverbed \\
\hline Geological structure & Erosion of residual soils & Erosion of residual soils \\
\hline Mechanism of occurrence & $\begin{array}{l}\text { Landslides and accumulation of material } \\
\text { in the river bed }\end{array}$ & $\begin{array}{l}\text { Landslides and accumulation of } \\
\text { material in the river bed }\end{array}$ \\
\hline Transportation mechanism & Highly non-stationary and pulsating & Highly non-stationary and pulsating \\
\hline Effect on the river bed & Erosive & Erosive \\
\hline Volume of the event & $\begin{array}{l}\text { Medium } \\
\text { (between 10,000 } \mathrm{m}^{3} \text { and 100,000 } \mathrm{m}^{3} \text { ) }\end{array}$ & $\begin{array}{l}\text { Medium } \\
\text { (between 10,000 } \mathrm{m}^{3} \text { and } 100,000 \mathrm{~m}^{3} \text { ) }\end{array}$ \\
\hline Recurrence of the event & Low (Frequency more than 10 years) & $\begin{array}{l}\text { Low } \\
\text { (Frequency more than } 10 \text { years) }\end{array}$ \\
\hline Type of flow & Between mud and debris flow & Between mud and debris flow \\
\hline Flow characteristic & Pulsating, one wave & Pulsating, several waves \\
\hline Granulometry & $\begin{array}{l}\text { Coarse granulometry (pebbles, gravels, } \\
\text { sands and fines) }\end{array}$ & $\begin{array}{l}\text { Coarse granulometry (pebbles, } \\
\text { gravels, sands and fines) }\end{array}$ \\
\hline Density & $1900 \mathrm{~kg} / \mathrm{m}^{3}$ & $1900 \mathrm{~kg} / \mathrm{m}^{3}$ \\
\hline Viscosity & $\begin{array}{l}\text { High viscosity } \\
\text { (greater than } 1000 \text { water viscosity) }\end{array}$ & $\begin{array}{l}\text { High viscosity } \\
\text { (greater than } 1000 \text { water viscosity) }\end{array}$ \\
\hline Speed & Medium & Medium \\
\hline
\end{tabular}

$$
C_{v}=\frac{\gamma_{b} S}{\left(\gamma_{s}-\gamma_{b}\right)(\operatorname{tg} \emptyset-S)}
$$

where:

$\gamma_{b} \quad$ Specific gravity of the mud $\left(1.0 \div 1.6 \mathrm{ton} / \mathrm{m}^{3}\right)$

$\gamma_{s} \quad$ Specific weight of the solid material $\left(2.6 \mathrm{ton} / \mathrm{m}^{3}\right)$

$S \quad$ Middle slope of the stream bed

$\phi \quad$ Internal friction angle of solid material $\left(30^{\circ} \div 35^{\circ}\right)$

The maximum flow rate of mud flow with respect to water flow and material in suspension is Equation 2:

$$
Q_{b}=\frac{\gamma_{s}-\gamma}{\gamma_{s}-\gamma_{b}} Q_{l}
$$

being:

$\gamma$ Specific weight of water $\left(1.0 \mathrm{ton} / \mathrm{m}^{3}\right)$

$Q_{l}$ Maximum liquid or water flow $\left(\mathrm{m}^{3} / \mathrm{s}\right)$

$Q_{b}$ Maximum mud flow $\left(\mathrm{m}^{3} / \mathrm{s}\right)$

The maximum flow of debris flow in saturated condition results in Equation 3:

$$
Q_{h}=\frac{C^{*}}{C^{*}-C_{v}} Q_{l}
$$

being:

$C^{*}$ Maximum concentration of solid material at rest (0.6)

According to Sokolov's formula (1968), the maximum flow of debris flow is estimated according to the maximum water flow Equation 4:

$Q_{h}=K(1+\beta) Q_{l}$

where:

$Q_{h}$ Maximum flow rate of debris flow $\left(\mathrm{m}^{3} / \mathrm{s}\right)$

$Q_{l} \quad$ Maximum water flow $\left(\mathrm{m}^{3} / \mathrm{s}\right)$

$K$ Coefficient of biphasic mixing of the bed of the stream

$\beta$ coefficient of solids and fluid content (is equivalent to $\mathrm{Cv}$ ) 
The coefficients $K$ for the streams take values of $K=3.0$. To estimate the values of $\beta$, the incidence of medium to high-concentration debris flow in the Mirave 1 stream $(\beta=0.35)$, and of medium concentration in the rest of the three streams $(\beta=0.30)$ is considered. In Table 3 , the peak flows of water flow in the four micro watersheds of Mirave's watershed are shown.

Table 3. Estimated peak liquid flows $\left(\mathrm{m}^{3} / \mathrm{s}\right)$ for the 04 micro-watersheds.

\begin{tabular}{lccccc}
\hline \multirow{2}{*}{ Micro-watersheds } & \multicolumn{5}{c}{$\mathbf{Q}_{\boldsymbol{1}}$ peak for return periods (years) } \\
\cline { 2 - 6 } & $\mathbf{T R = 2 5}$ & $\mathbf{T R = 5 0}$ & $\mathbf{T R = 1 0 0}$ & $\mathbf{T R = 2 0 0}$ & $\mathbf{T R = 5 0 0}$ \\
\hline Mirave 1 Stream & 11.5 & 14.8 & 18.4 & 22.3 & 27.7 \\
Mirave 2 Stream & 4.5 & 5.8 & 7.2 & 8.7 & 10.8 \\
Mirave 3 Stream & 2.7 & 3.6 & 4.4 & 5.4 & 6.7 \\
Mirave 4 Stream & 3.8 & 4.9 & 6.1 & 7.4 & 9.2 \\
Mirave's watershed & 20.9 & 27.1 & 33.5 & 40.6 & 50.4 \\
\hline
\end{tabular}

In Table 4, estimates of the maximum flows of mud flows (Takahashi formula) are presented, in the output section of each of the streams, and for different periods of return. Likewise, the maximum flows of debris flows are presented considering the Sokolov formula. In the results, it is observed that the values obtained with the Takahashi formula are reasonable and congruent with the geomorphological conditions of watersheds areas, as well as by the driving capacity and traces left in the sections of streams during the debris flow of 2019. However, the maximum flows obtained with Sokolov's formula are high values for debris flows that occurred in Mirave's watershed. This is explained by the fact that the formula of Takahashi is valid between mud flows and debris flows. Rheologically, the biphasic mixture of mud events that occurred in Mirave's watershed correspond to mud materials with a low presence of coarse materials (rocks and stones), typical of mud flows.

\subsection{Hydrographs and volume of the debris flow in the four streams of Mirave's watershed estimation}

Figures 4, 5, 6 and 7 show the flow hydrographs of debris flows for different periods of return of the four main streams of Mirave's watershed, constructed from hydrographs of liquid or water flows, and from the peaks of discharge of calculated debris flows. The volumes of water were determined by calculating the envelope area of flood hydrographs for different return periods. According to the methodology proposed by Quisca (2010), and suggested by Shen et al. (2018), volumes of hydrographs of debris flows were obtained for different periods of return. Table 5 shows the estimates of maximum volumes of mud events for different return periods, in the output sections of each of the four streams of Mirave's watershed.

The maximum volumes of debris flows estimated for the return periods of $\mathrm{TR}=25$ years, 50 years, 100 years, 200 years and 500 years of watersheds of Mirave 1, Mirave 2, Mirave 3 and Mirave 4 Streams are congruent with geomorphological conditions, high availability of detrital material and no vegetation coverage in Mirave's watershed.

In fact, the low values of the average annual sediment production of the suggested streams are due to the nearly dry condition of Mirave's watershed, where it rarely rains. However, when the wet area of Ilabaya's watershed moves towards lower levels, intense rains and extreme rains occur in Mirave's watershed (that forms part of Ilabaya's watershed), with the consequent intensification of solid production by water erosion, both on stream slopes and beds. 
Table 4. Estimation of maximum debris flows for different return periods.

\begin{tabular}{|c|c|c|c|c|c|c|c|c|c|c|c|c|c|c|c|c|c|c|c|c|c|c|c|}
\hline \multirow{3}{*}{$\begin{array}{l}\text { Maximum } \\
\text { flow }\left(\mathbf{m}^{3} / \mathbf{s}\right)\end{array}$} & \multirow{3}{*}{$C_{d}$} & \multirow{3}{*}{$K$} & \multirow{3}{*}{$\beta$} & \multicolumn{5}{|c|}{ Mirave 1 Stream } & \multicolumn{5}{|c|}{ Mirave 2 Stream } & \multicolumn{5}{|c|}{ Mirave 3 Stream } & \multicolumn{5}{|c|}{ Mirave 4 Stream } \\
\hline & & & & \multicolumn{5}{|c|}{ Return Period (years) } & \multicolumn{5}{|c|}{ Return Period (years) } & \multicolumn{5}{|c|}{ Return Period (years) } & \multicolumn{5}{|c|}{ Return Period (years) } \\
\hline & & & & 25 & 50 & 100 & 200 & 500 & 25 & 50 & 100 & 200 & 500 & 25 & 50 & 100 & 200 & 500 & 25 & 50 & 100 & 200 & 500 \\
\hline Water flow & - & - & - & 11.5 & 14.8 & 18.4 & 22.3 & 27.7 & 4.5 & 5.8 & 7.2 & 8.7 & 10.8 & 2.7 & 3.6 & 4.4 & 5.4 & 6.7 & 3.8 & 4.9 & 6.1 & 7.4 & 9.2 \\
\hline \multirow{3}{*}{$\begin{array}{l}\text { Flow rate } \\
\text { of mud } \\
\text { Debris } \\
\text { flow } \\
\text { (Takahashi } \\
\text { formula) }\end{array}$} & - & - & - & 14.15 & 18.22 & 22.65 & 27.45 & 34.09 & 5.54 & 7.14 & 8.86 & 10.71 & 13.29 & 3.32 & 4.43 & 5.42 & 6.65 & 8.25 & 4.68 & 6.03 & 7.51 & 9.11 & 11.32 \\
\hline & 0.191 & - & - & 20.74 & 26.69 & 33.19 & 40.22 & 49.96 & 8.12 & 10.46 & 12.99 & 15.69 & 19.48 & 4.87 & 6.49 & 7.94 & 9.74 & 12.08 & 6.85 & 8.84 & 11.00 & 13.35 & 16.59 \\
\hline & & 3.0 & 3.5 & & & & & & & & & & & & & & & & & & & & \\
\hline \multirow{3}{*}{$\begin{array}{l}\text { Debris } \\
\text { flow } \\
\text { (Sokolov } \\
\text { formula) }\end{array}$} & - & 3.0 & 3.0 & 46.58 & 59.94 & 74.52 & 90.32 & 112.2 & 17.55 & 22.62 & 28.08 & 33.93 & 42.12 & 10.53 & 14.04 & 17.16 & 21.06 & 26.13 & 14.82 & 19.11 & 23.79 & 28.86 & 35.88 \\
\hline & & 3.0 & 3.0 & & & & & & & & & & & & & & & & & & & & \\
\hline & & 3.0 & 3.0 & & & & & & & & & & & & & & & & & & & & \\
\hline
\end{tabular}

Table 5. Estimation of maximum volumes of debris flows for different return periods.

\begin{tabular}{|c|c|c|c|c|c|c|c|c|c|c|c|c|c|c|c|c|c|c|c|c|}
\hline \multirow{3}{*}{ Variable } & \multicolumn{5}{|c|}{ Mirave 1 Stream } & \multicolumn{5}{|c|}{ Mirave 2 Stream } & \multicolumn{5}{|c|}{ Mirave 3 Stream } & \multicolumn{5}{|c|}{ Mirave 4 Stream } \\
\hline & \multicolumn{5}{|c|}{ Return Period (years) } & \multicolumn{5}{|c|}{ Return Period (years) } & \multicolumn{5}{|c|}{ Return Period (years) } & \multicolumn{5}{|c|}{ Return Period (years) } \\
\hline & 25 & 50 & 100 & 200 & 500 & 25 & 50 & 100 & 200 & 500 & 25 & 50 & 100 & 200 & 500 & 25 & 50 & 100 & 200 & 500 \\
\hline $\begin{array}{l}\text { Peak flow of the } \\
\text { water hydrograph } \\
\left(\mathrm{m}^{3} / \mathrm{s}\right)\end{array}$ & 11.5 & 14.8 & 18.4 & 22.3 & 27.7 & 4.5 & 5.8 & 7.2 & 8.7 & 10.8 & 2.7 & 3.6 & 4.4 & 5.4 & 6.7 & 3.8 & 4.9 & 6.1 & 7.4 & 9.2 \\
\hline $\begin{array}{l}\text { Hydrogram water } \\
\text { volume }\left(\mathrm{m}^{3}\right) \times 10^{3}\end{array}$ & 150.6 & 184.5 & 221.3 & 266.5 & 319.9 & 73.5 & 88.3 & 105.7 & 125.3 & 152.5 & 25.03 & 30.19 & 36.22 & 43.40 & 53.14 & 51.3 & 63.8 & 78.9 & 91.4 & 112.2 \\
\hline $\begin{array}{l}\text { Peak of debris } \\
\text { flow }\left(\mathrm{m}^{3} / \mathrm{s}\right)\end{array}$ & 20.74 & 26.69 & 33.19 & 40.22 & 49.96 & 8.12 & 10.46 & 12.99 & 15.69 & 19.48 & 4.87 & 6.49 & 7.94 & 9.74 & 12.08 & 6.85 & 8.84 & 11.00 & 13.35 & 16.59 \\
\hline $\begin{array}{l}\text { Maximum } \\
\text { volume of debris } \\
\text { flow }\left(\mathrm{m}^{3}\right) \times 10^{3}\end{array}$ & 271.7 & 334.1 & 397.6 & 482.0 & 579.3 & 131.6 & 159.8 & 189.5 & 226.8 & 273.6 & 44.4 & 53.5 & 66.3 & 77.1 & 95.7 & 92.9 & 113.7 & 141.0 & 165.5 & 203.2 \\
\hline
\end{tabular}




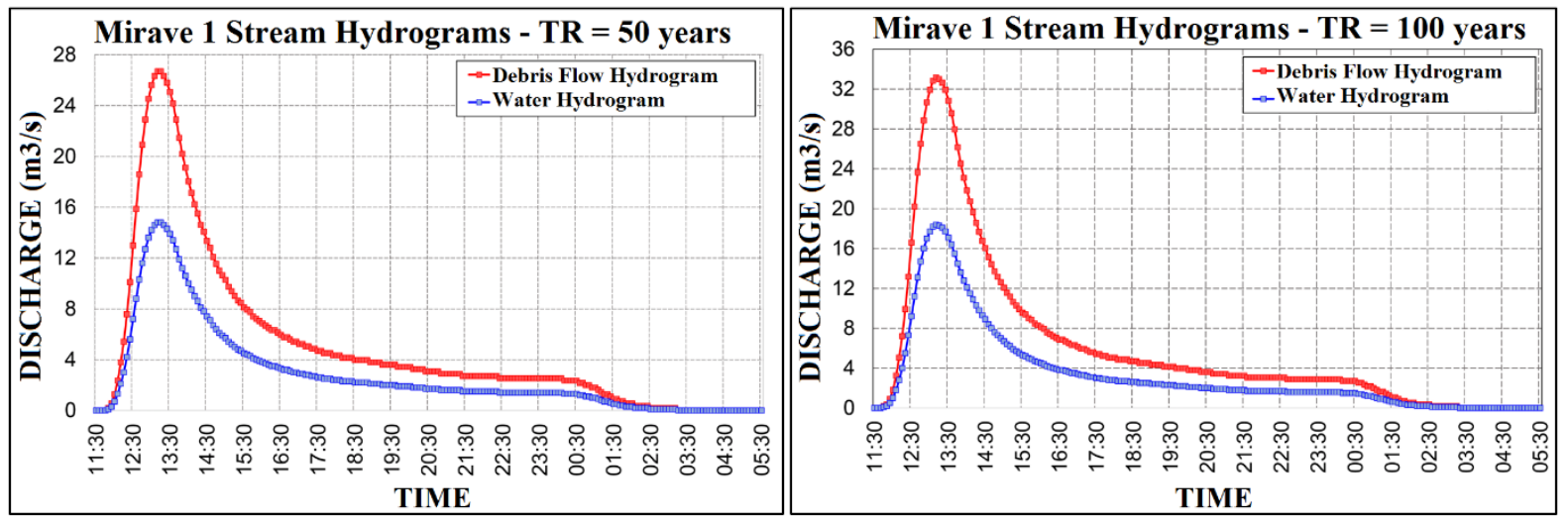

Figure 4. Hydrograms of debris flows for Mirave 1 Streams - TR $=50$ and 100 years.
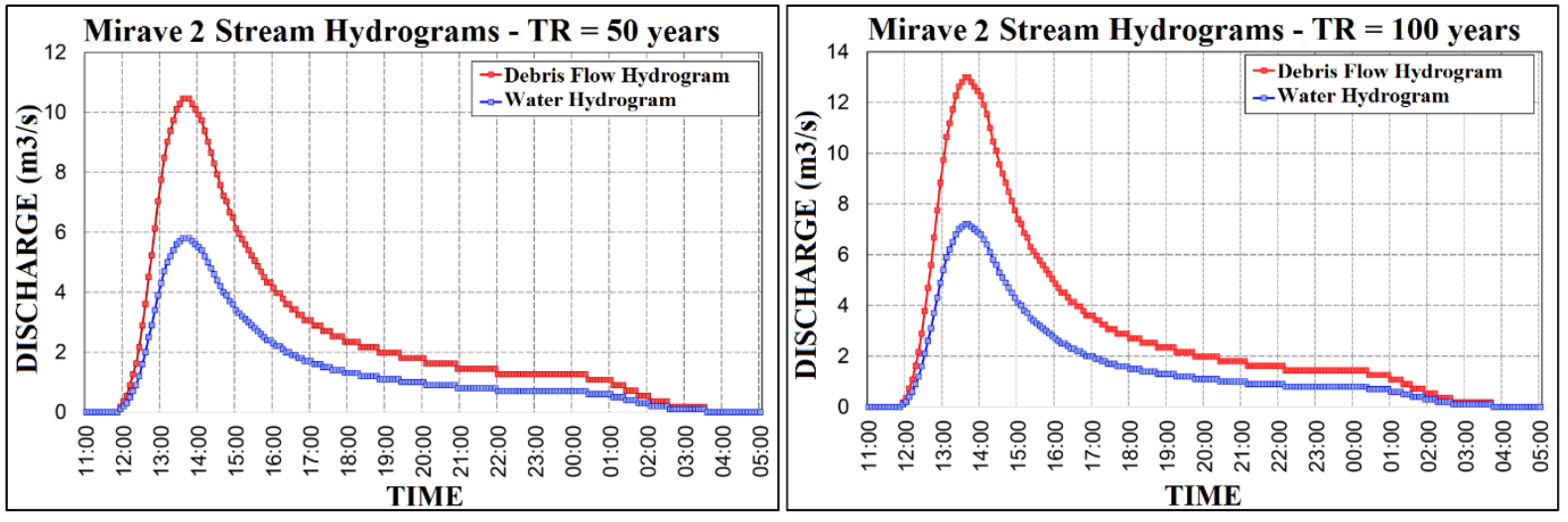

Figure 5. Hydrograms of debris flows for Mirave 2 Streams - TR $=50$ and 100 years.
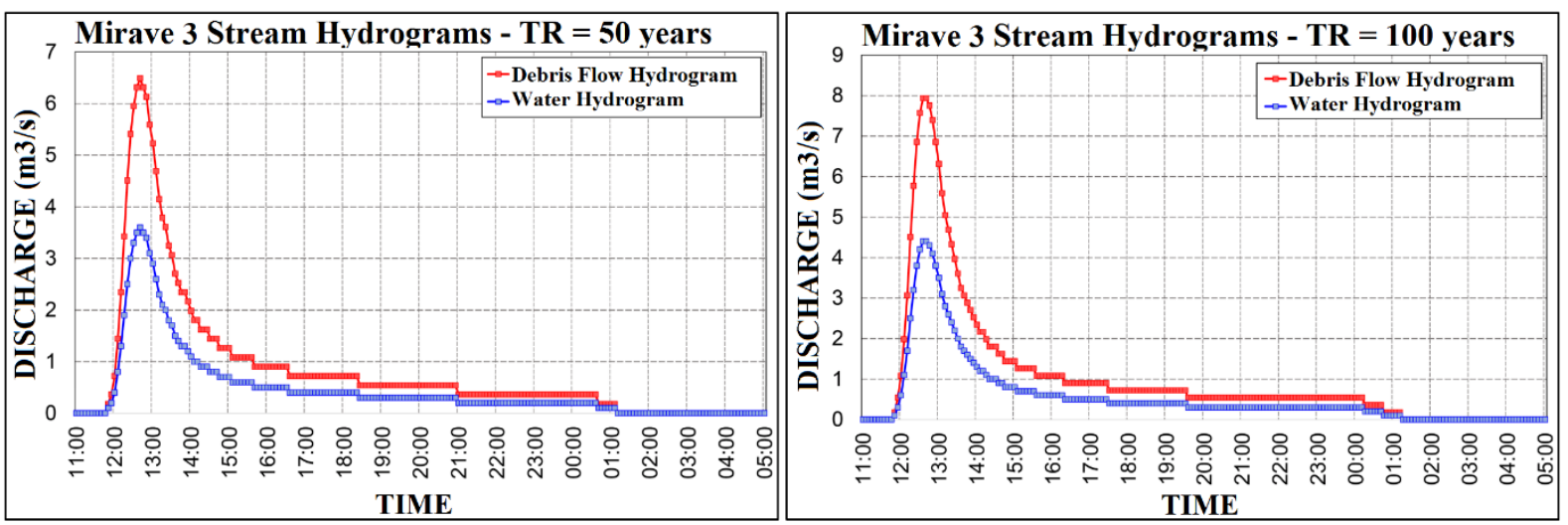

Figure 6. Hydrograms of debris flows for Mirave 3 Streams - TR $=50$ and 100 years.
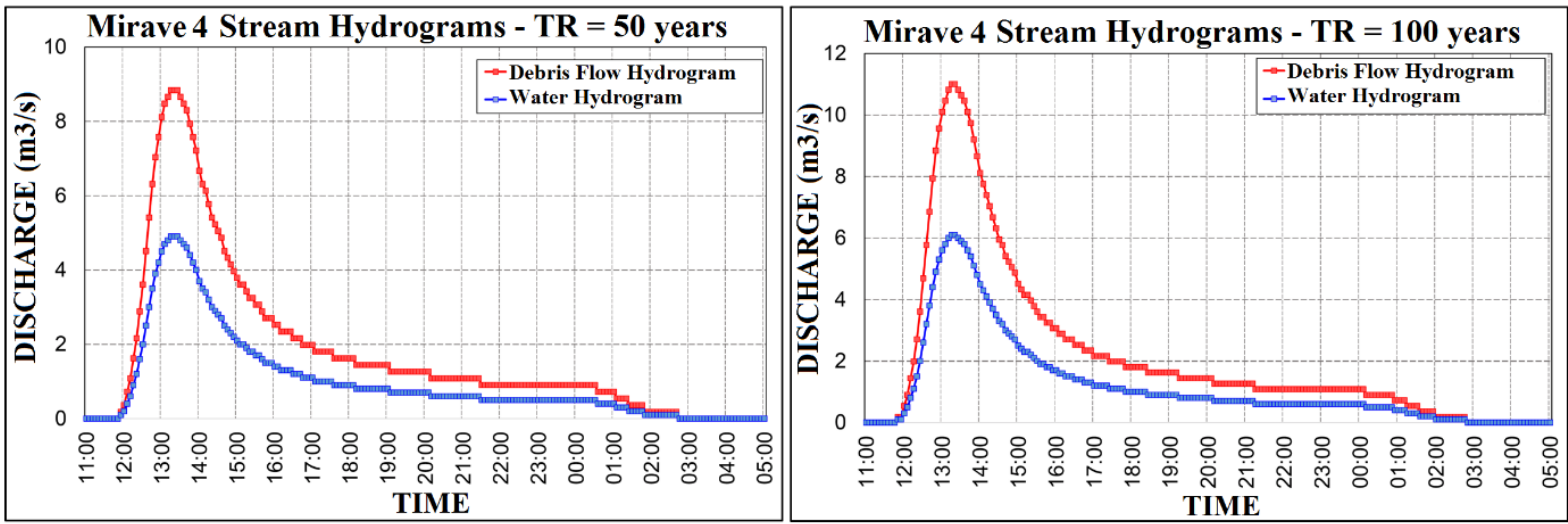

Figure 7. Hydrograms of debris flows for the Mirave 4 Streams - TR $=50$ and 100 years. 
Mizuyama (2008) and Mizuyama and Kobashi (1992), produced a graph from the registered database of peak flows and their corresponding volumes of watershed squibs with debris flow events. Plotting the estimated values of the peak flow of debris (for different return periods) and their corresponding volumes of debris flows (values from Table 5), the results presented in Figure 8 were obtained. In this figure, it is observed that all pairs of estimated and plotted data are located within the registered data cloud. The plotted points of the estimated values for the four streams of Mirave watershed are located within the region of registered data of debris flows. Therefore, the estimated values of peak flows and maximum volumes of mud events for the four streams of Mirave's watershed are credible values for engineering design purposes, given that they are consistent with the values contrasted in field, and with the registered database of debris flow events in watersheds, reported by Mizuyama et al. (1992).

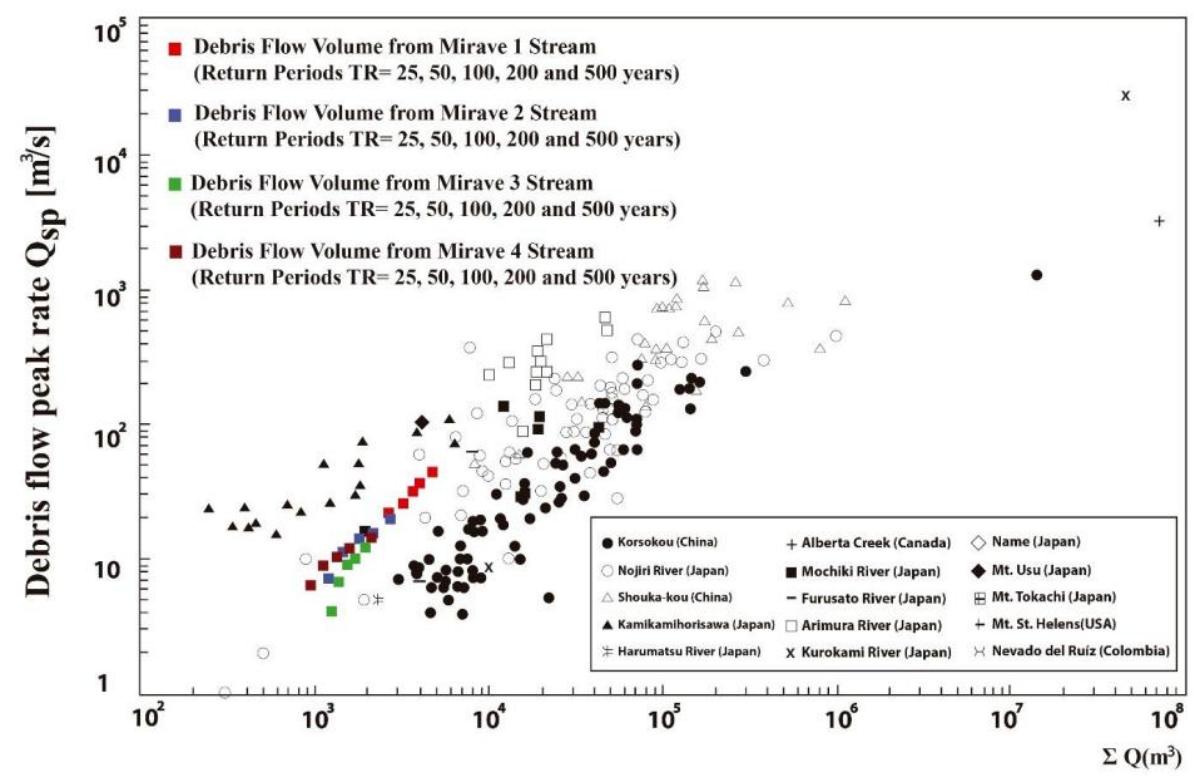

Figure 8. Relationship between debris flow total volumes and peak discharges (Mizuyama et al., 1992).

\subsection{Rheological parameters of debris flow}

In numerical simulations with the FLO-2D model, the values of parameters $\alpha_{1}=0.006032$, $\beta_{1}=19.9, \alpha_{2}=0.000707$, and $\beta_{2}=29.8$ were used, which have been selected from values reported by Wu et al. (2013), with the help of lithological and geomorphological characteristics similar to those found in Mirave's watershed.

\subsection{Method of modeling and simulation of the debris flow}

As the streams of Mirave's watershed are dry nearly all year round and are activated only during heavy or extreme rainfall, they do not have a register of flow gauges of streams, much less of the sediment load. This lack of information makes it difficult to estimate the production of sediments and maximum flows for different periods of return, which represents input information to propose structural measures to reduce the damage caused by mudslide events.

For modeling and simulation of the debris flow of February, 2019in Mirave's watershed, a photogrammetric survey using a drone was made in July 2018, which shows the topography of the land before the occurrence of the debris flow.

\subsubsection{Scenarios of flow modeling of debris flows in Mirave's watershed}

Modeling scenarios were established for debris flows considering the simultaneous activation of the four streams of Mirave's watershed, and the activation of part of the streams, oriented to reproduce the debris flow that occurred in February, 2019 (Table 6). 
Table 6. Relationship-modeling scenarios and numerical simulations performed with FLO-2D software.

\begin{tabular}{cccc}
\hline FLO-2D Simulation & Scenario & Return Periods - TR (years) & Flow Type \\
\hline $\mathrm{N}^{\circ} 1$ & $\mathrm{C} 1+2, \mathrm{C} 3$, and C4 & 25 & Water \\
$\mathrm{N}^{\circ} 2$ & $\mathrm{C} 1+2, \mathrm{C} 3$, and C4 & 50 & Water \\
$\mathrm{N}^{\circ} 3$ & $\mathrm{C} 1+2, \mathrm{C} 3$, and C4 & 100 & Water \\
$\mathrm{N}^{\circ} 4$ & $\mathrm{C} 1+2$ & 25 & Water \\
$\mathrm{N}^{\circ}$ & $\mathrm{C} 1+2$ & 50 & Water \\
$\mathrm{N}^{\circ} 6$ & $\mathrm{C} 1+2$ & 100 & Water \\
$\mathrm{N}^{\circ} 7$ & $\mathrm{C} 1+2, \mathrm{C} 3$, and C4 & 50 & Hyperconcentrated flow $(\mathrm{Cv}=0.30)$ \\
$\mathrm{N}^{\circ} 8$ & $\mathrm{C} 1+2, \mathrm{C} 3$, and $\mathrm{C} 4$ & 100 & Hyperconcentrated flow $(\mathrm{Cv}=0.30)$ \\
$\mathrm{N}^{\circ}$ & $\mathrm{C} 1+2$ & 50 & Hyperconcentrated flow $(\mathrm{Cv}=0.30)$ \\
$\mathrm{N}^{\circ} 10$ & $\mathrm{C} 1+2$ & 100 & Hyperconcentrated flow $(\mathrm{Cv}=0.30)$ \\
$\mathrm{N}^{\circ} 11$ & $\mathrm{C} 1+2, \mathrm{C} 3$, and C4 & 50 & Debris flow $(\mathrm{Cv}=0.45)$ \\
$\mathrm{N}^{\circ} 12$ & $\mathrm{C} 1+2, \mathrm{C} 3$, and $\mathrm{C} 4$ & 100 & Debris flow $(\mathrm{Cv}=0.45)$ \\
$\mathrm{N}^{\circ} 13$ & $\mathrm{C} 1+2$ & 50 & Debris flow $(\mathrm{Cv}=0.45)$ \\
$\mathrm{N}^{\circ} 14$ & $\mathrm{C} 1+2$ & 100 & Debris flow $(\mathrm{Cv}=0.45)$ \\
\hline
\end{tabular}

\subsubsection{Numerical simulations of debris-flow scenarios}

Considering the classification and characterization of the debris flow that occurred on February $8^{\text {th }}, 2019$ in the four streams of Mirave's watershed (Tables 1 and 2), and considering the different rheological models used by the existing numerical models, the commercial software FLO-2D has been selected for the application to the present study. The rheology of the debris flow that occurred in the streams of Mirave correspond to mud flows with low content of stones and thick materials, which can be modeled with the rheological model of quadratic stress proposed by O'Brien et al. (1993), which describes behavior from viscous flow to turbulentdispersive flow. The FLO-2D has been used in numerous studies of mudflows in different parts of the world, with acceptable results for engineering purposes, O'Brien et al. (1993), Garcia and López (2005), Hsu et al. (2010), Castelli et al. (2017), and others.

In the modeling and numerical simulations of debris flows with the FLO-2D, it is necessary to assume the hypotheses adopted by the referred model, as a homogeneous fluid, fixed or nonerodible bed, and constant rheological parameters throughout the transport and deposition of mudslide flows. However, the channel of the main stream of Mirave's watershed actually suffers the effects of erosion due to the intensity of abrasion and erosion of the biphasic flow, which is much higher than water flow. In the simulation, erosion zones are identified in areas with high or erosive velocities. The areas where the solids from flow of deposits are deposited will be in natural topographic depressions or in artificial depressions (such as the football stadium). Given that the apex of the fan or dejection cone is well-defined, and Mirave's streets are located in the same dejection cone, the debris will flow through the streets and drain towards the Ilabaya River, since the existing covered drainage channel was overwhelmed by the high flows involved in the debris flow event.

The results of numerical simulations $\mathrm{N}^{\circ} 2, \mathrm{~N}^{\circ} 3, \mathrm{~N}^{\circ} 7$ and $\mathrm{N}^{\circ} 8$, corresponding to the water and hyperconcentrated flow rheology, for return periods of 50 and 100 years, indicate that the field of maximum and maximum stresses velocities reproduce the extension of the areas affected by the event of debris flow of 2019 , mainly the solid deposition areas. The velocity field acceptably represents the flow velocity values in Mirave's streets. However, the velocity field inappropriately represents the erosion zones observed in the field, mainly downstream of existing sediment retention dikes.

In the case of numerical simulations corresponding to the flow hydrographs of debris flows, the graphical outputs shown in Figures 9 and 10 (numerical simulations $\mathrm{N}^{\circ} 12$, for return periods of 100 years), show acceptable results in terms of reproduction of the extent of the affectation and areas of solid deposition, and the velocity field shows an improvement in the adequate representation of the erosion zones observed in the field. 


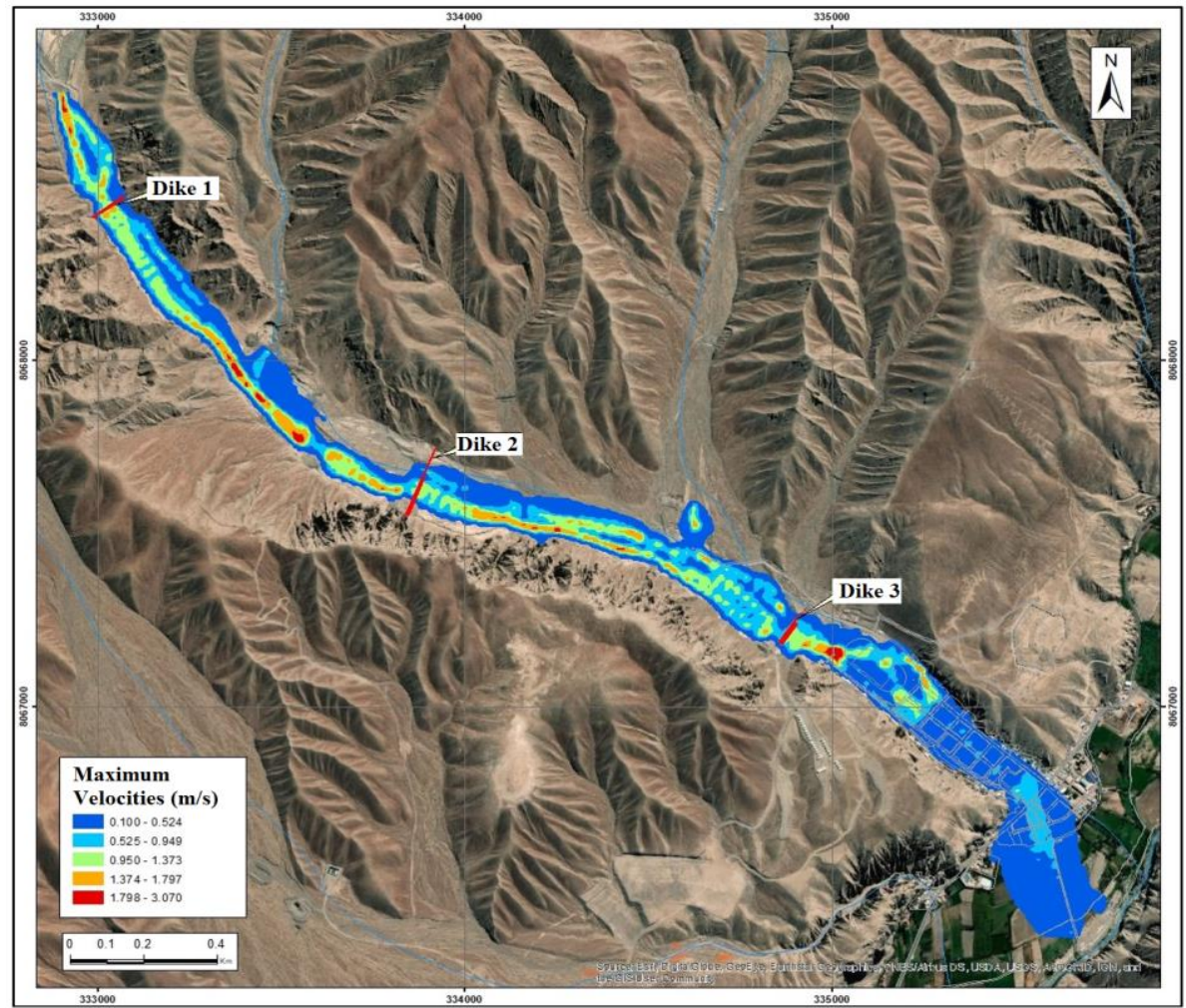

Figure 9. Graphic output of the velocity field in the computational domain of the results of numerical simulation of the flow of debris, considering the activation of Mirave 1 Stream, Mirave 2 Stream, Mirave 3 Stream and Mirave 4 Stream, for a Return Period TR $=100$ years.

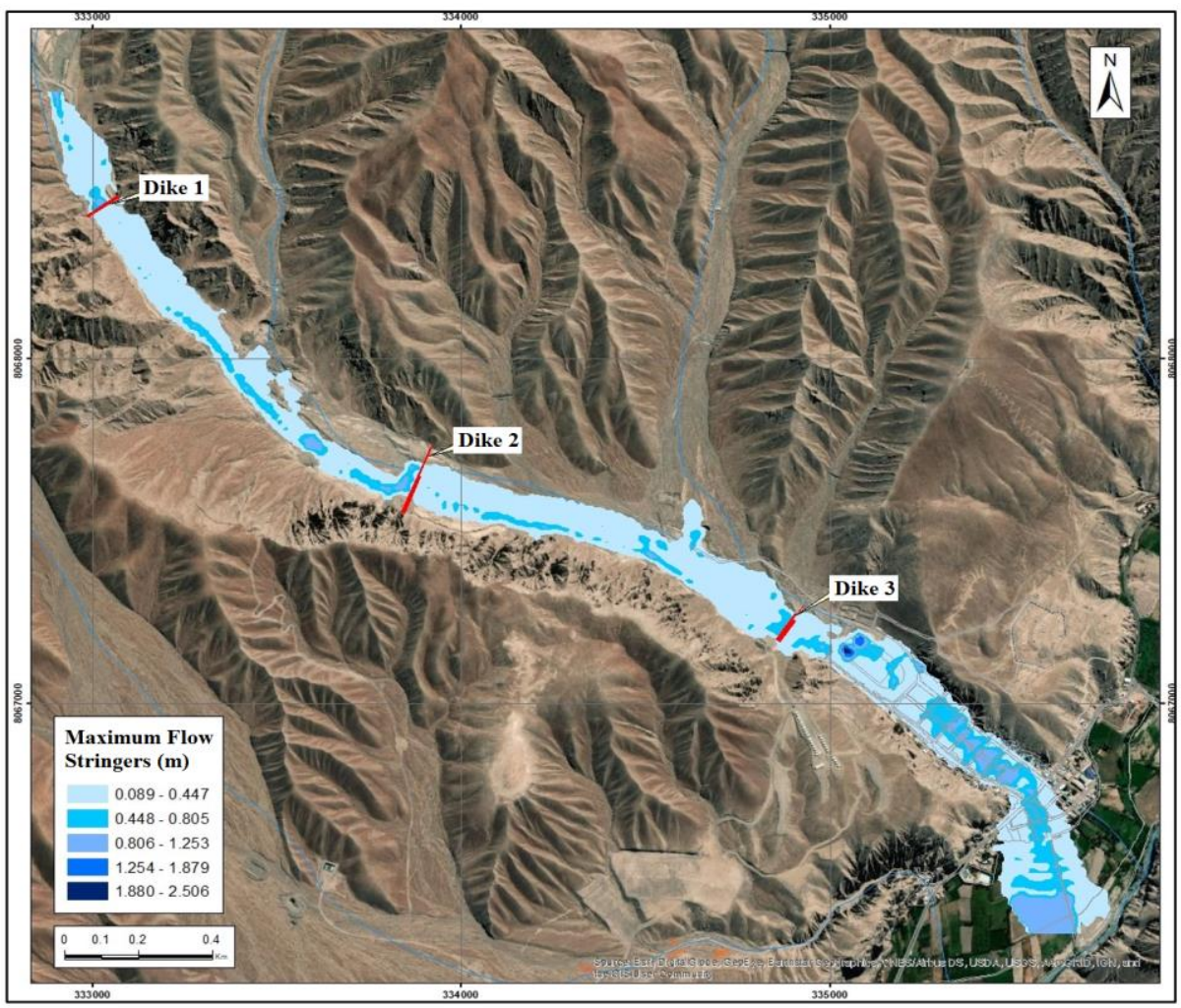

Figure 10. Graphic output of strain fields in computational domain of results of numerical simulation of debris flow, considering the activation of Mirave 1 Stream, Mirave 2 Stream, Mirave 3 Stream and Mirave 4 Stream, for a Return Period TR $=100$ years. 
The numerical simulations of mudflows for a 50-year return period (numerical simulations $\mathrm{N}^{\circ}$ 12) show results that do not reproduce the extension of the impact/damage produced by the debris flows of 2019.

\section{RESULTS AND DISCUSSION}

\subsection{Validation of the applied model}

The validation of the FLO-2D M odel applied to the reproduction of the transport and deposition processes of the debris flow which occurred on February $8^{\text {th }}, 2019$ was carried out mainly through the verification of the reproduction of critical areas of sedimentation and erosion, with the understanding that the extension of the areas affected by the debris flow was already verified for water flow, hyperconcentrated flow and mud flow simulations, corresponding to a 100-year return period. However, the verification of the accuracy of numerical simulations must be conducted in the existing sediment retention dams, stadium area, Mirave's watershed outlet mouth section, which transversally crosses the existing road, and in the main streets located in the dejection cone and existing drainage channel, which discharges into the Ilabaya River. Figure 2 shows the location of Mirave's community, which occupies the entire drainage outlet mouth of Mirave's watershed, as well as the apex and central part of the dejection cone.

Figure 11 shows the location and configuration of the solid retaining dam (Dike 1) in Mirave 1 Stream. The sediment retention structure is comprised of the dike with landfill and a dissipation pool. The drone image photogrammetry taken in July, 2018 shows that solid storage vessel cleaning did not restore the storage capacity of solids from Dike 1, which was filled by the debris flow event of 2015. Figure 11 shows the undermining suffered by the foundation of part of the dissipation pool of Dike 1 due to the passage of the debris flow of 2019. In the plan view of Dike 1 of Figure 11, undermining can be seen in waters below the Dike 1 dissipation pool, which was produced by debris flow of 2015 .
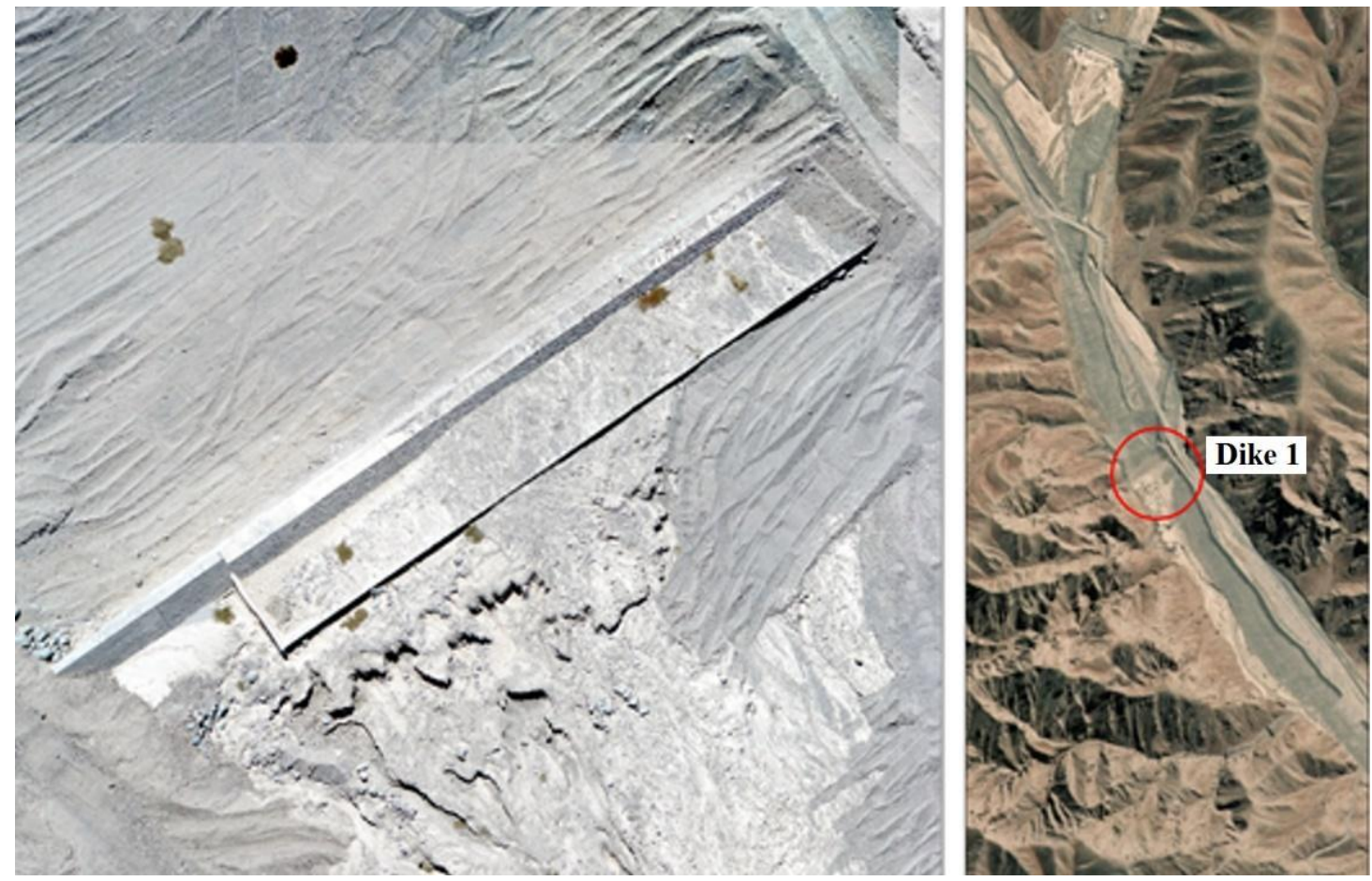

Figure 11. View of drone photogrammetry (July, 2018) of sediment retention dam (Dike 1), located in Mirave's main stream; and operational state of dike and sinkhole before the debris flow of 2019. 
In Figure 9, it is observed that the numerical simulation reproduces the moderated erosive velocities downstream of the Dike 1 dissipation pool. In relation to the sedimentation process of the sediment retention dam, Figures 9 and 10 present the maximum flow stringers reached (from $0.5 \mathrm{~m}$ to $2.5 \mathrm{~m}$ ) with low- to high flow velocities (from $0.5 \mathrm{~m} / \mathrm{s}$ to $3.0 \mathrm{~m} / \mathrm{s}$ ) (Figure 12).

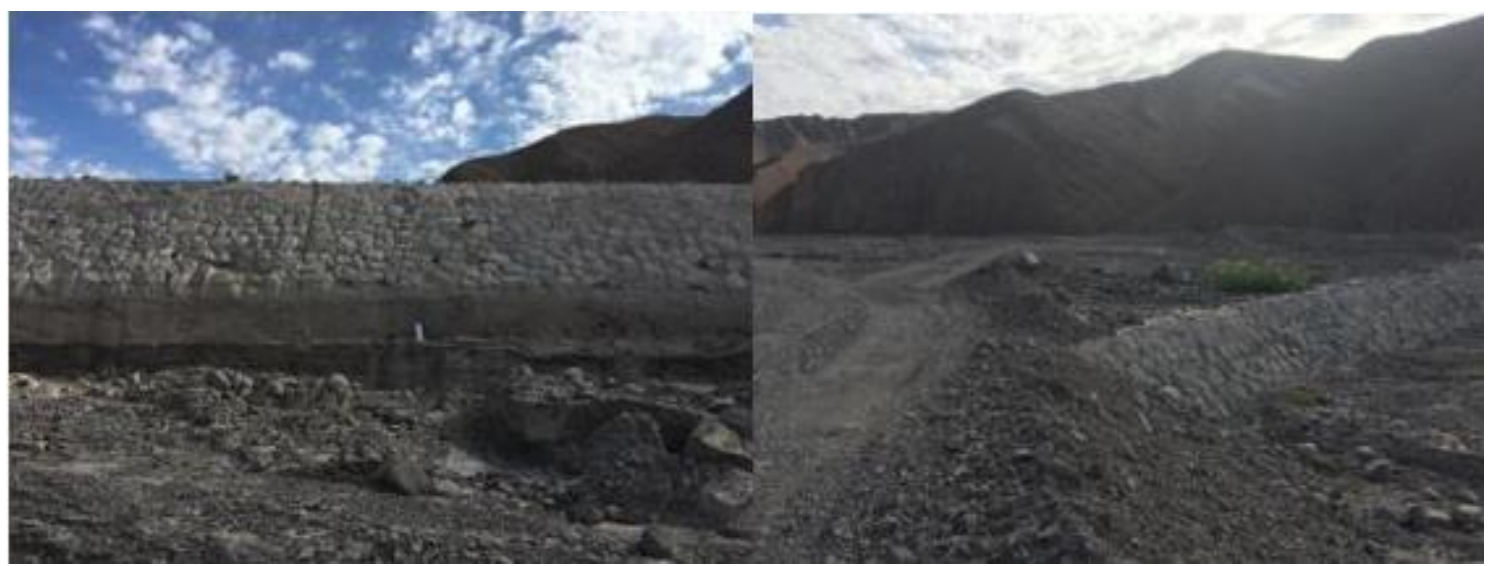

Figure 12. Left: View from Dike 1 downstream, where foundation undermining is shown below dam foundation and its dissipation pool after the debris flow of 2019. Right: The vessel of the dam clogged with solids by debris flow of 2019 .

Figure 13 shows the location and configuration of Dike 2 and its dissipation pool. The image of the drone photogrammetry made in July, 2018 shows traces of the cleaning of the solid storage vessel and downstream the dissipation pool. However, there is no restitution or increase in storage capacity of Dike 2, which was clogged by the debris flow of 2015. In Figure 9 , it is observed that numerical simulation reproduces the moderated erosive velocities that should exist downstream of the Dike 2 dissipation pool. In fact, in Figure 14 the intense regressive erosion occurred during the debris flow of 2019, which reached erosive speeds higher than $1.0 \mathrm{~m} / \mathrm{s}$. As shown in Figure 10, upstream of Dike 2, maximum strains of up to $1.2 \mathrm{~m}$ were formed, with velocities reaching $1.7 \mathrm{~m} / \mathrm{s}$.
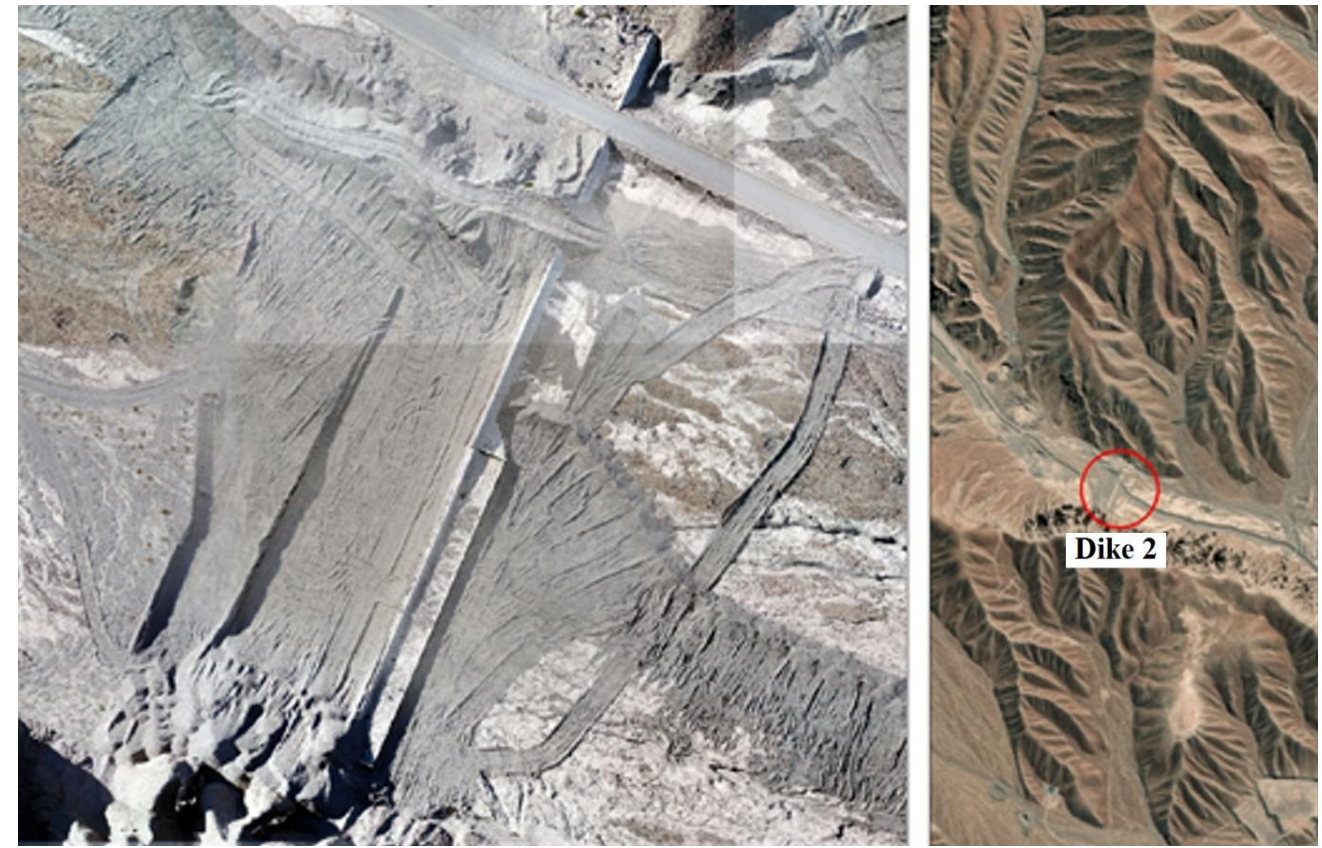

Figure 13. View of drone photogrammetry (July, 2018) of sediment retention dam (Dike 2), located in Mirave's main stream; and operational state of dike and sinkhole before the debris flow of 2019. 


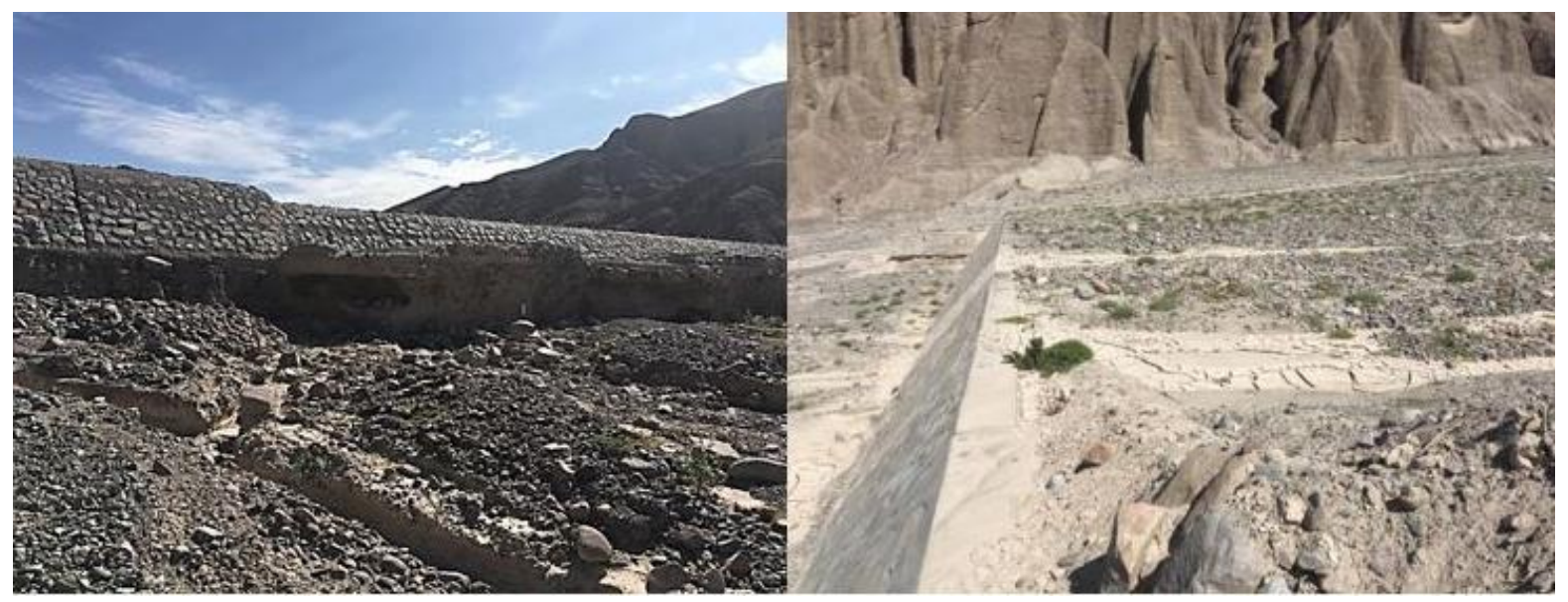

Figure 14. Left: View from downstream of Dike 2, showing the erosion and regressive erosion below the foundation of the dike and its dissipating pool after the debris flow event of 2019. Right: The dike vessel is shown sedimented with solids by effect of the debris flow of 2019.

Figure 15 presents the location and configuration of Dike 3, with its retaining wall and its sediment storage pond downstream of Dike 3. Figure 14 shows the structure of Dam 3 in its entirety with the confining wall for solid storage. The drone photogrammetry image (Figure 15), made in July, 2018, shows traces of the cleaning of the solid storage vessel and downstream; however, it also shows that the restitution or increase of storage capacity of Dike 3 was insufficient.
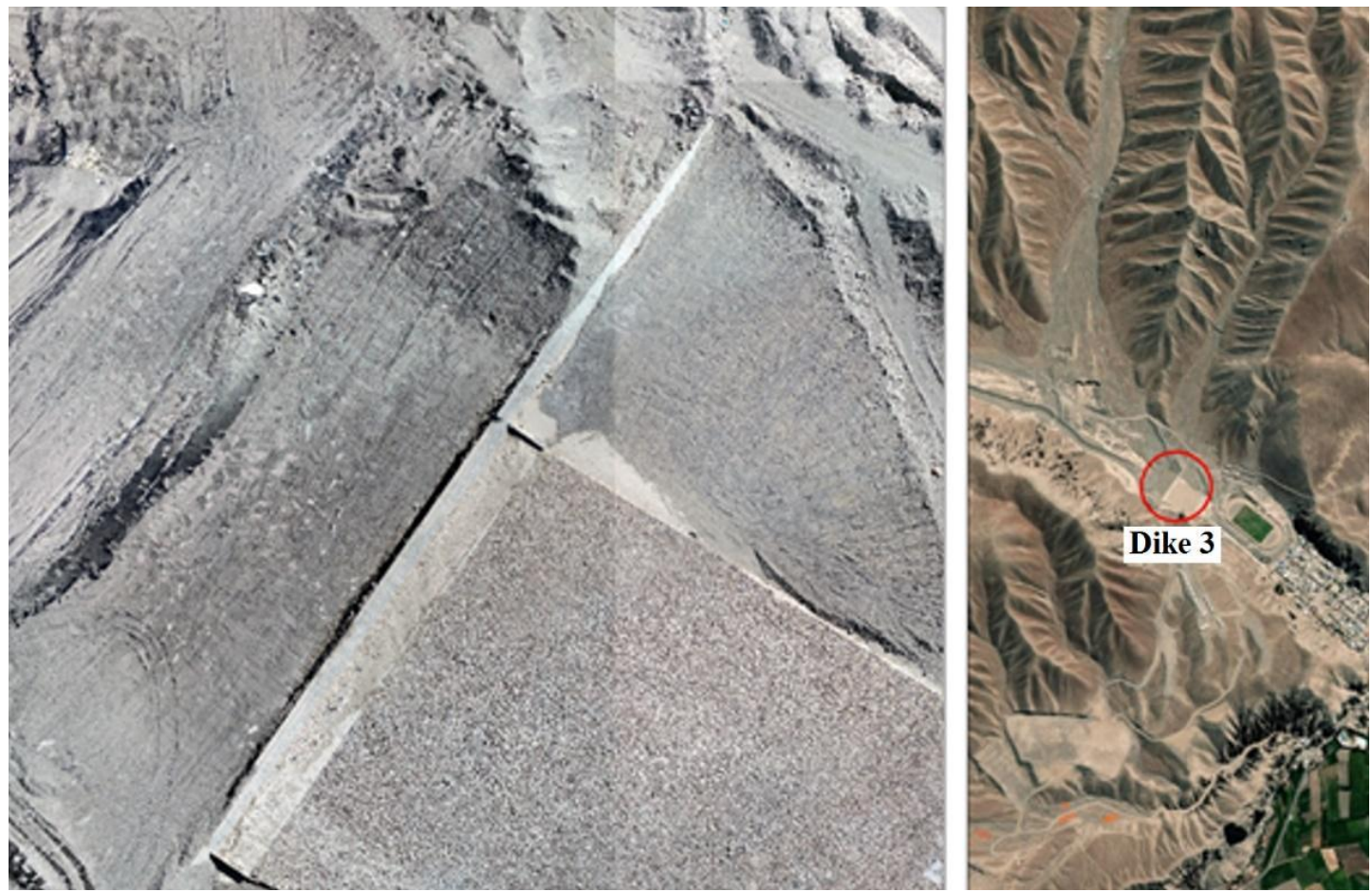

Figure 15. View of drone photogrammetry (July, 2018) of the sediment-retention dam (Dike 3), located in Mirave's main stream, upstream from the football stadium; and the operational state of the dike and sinkhole before the debris flow of 2019.

Figure 16 shows the structure of Dike 3 and the solid storage area, immediately downstream of the dam, and confined with a retaining wall with drainage (before the debris flow of 2019), located upstream of the football stadium. 


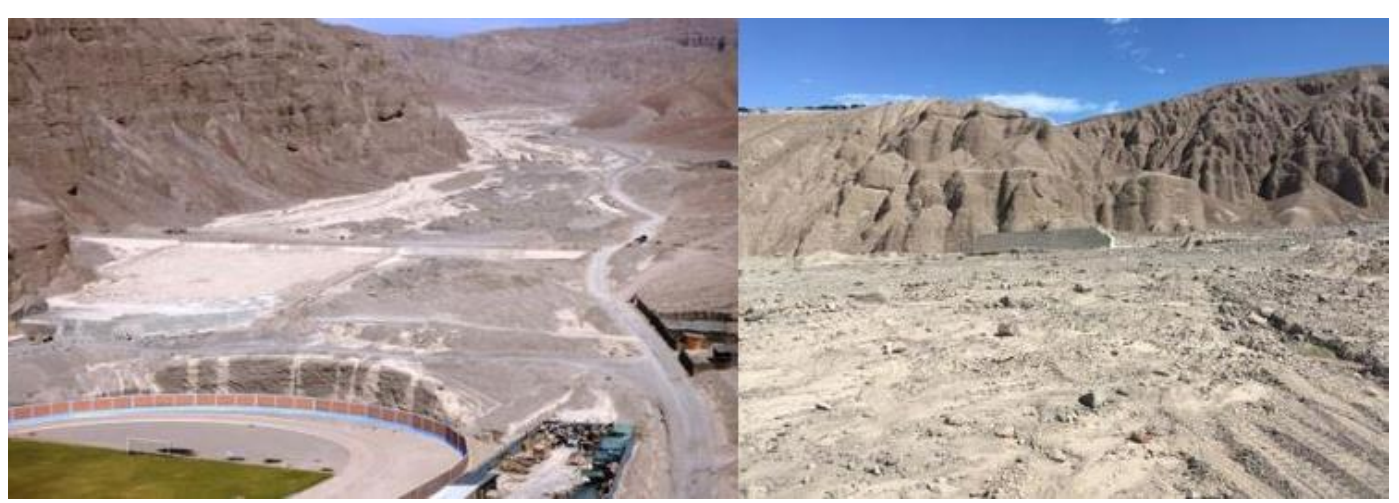

Figure 16. Left: View from downstream of Dike 3 before the debris flow of 2019, where the dike and its dissipation pool can be observed, and immediately downstream of the location of an additional protection containment wall, and football stadium. Right: The debris flow of 2019 devastated and overwhelmed the structure of Dike 3 and the football stadium, partially collapsing the retaining wall.

The debris flow of 2019 devastated and filled the structure of Dike 3 and the football stadium, partially collapsing. In Figure 9, it is observed that the velocity field reproduces the speeds downstream of Dike 3, as well as the velocities upstream from it.

Likewise, the velocity field and extension of the affected areas in the streets located in the ejection cone are reproduced satisfactory. The football stadium was completely filled with solids. Also, the destruction of reinforced concrete columns and perimeter walls of the football stadium was observed, which shows the high-impact strength of the 2019 debris flow.

\section{CONCLUSIONS}

Although a numerical modeling and simulation procedure is not yet available to predict or reproduce the entire physical process, from the initiation to the transport and the subsequent deposition of the debris flow, the proposed and applied procedure in the present research is valid for engineering purposes, and is part of a methodology for disaster risk assessment of debris flows in Peru.

The physical process of the initiation of debris flows can be represented in debris -flow hydrographs for different return periods calculated from the corresponding liquid flow hydrographs, which are congruent with geomorphological conditions, availability of detrital materials and the almost non-existent vegetative coverage of the micro watersheds of streams which define Mirave's watershed.

The estimated values of peak flows and maximum volumes of debris flow events for the four streams of the Mirave watershed are reliable for engineering design purposes and consistent with the values contrasted in the field and with the base of recorded data from debris flows events in watersheds reported by Mizuyama and Kobashi (1992).

The results of numerical simulations of the processes of the transport and deposition of the debris flow corresponding to the flow hydrographs of debris flows for a 100-year return period show acceptable results in terms of reproduction of the affected extent and deposition areas of solids from the debris flow of 2019. Moreover, the resulting velocity field shows an adequate representation of the erosion zones observed on site.

The model developed in FLO-2D software was able to predict and delimit, with acceptable accuracy, the affected areas of the debris flow of 2019 for a determined return period.

The proposed methodology for assessing the risk of disasters due to the debris flows in watersheds and streams, validated by the study of Mirave's watersheds, can be used to understand the extent of debris flow flooding in extreme weather events, as well as developing emergency plans, and for formulating disaster-management policies in Peru. 


\section{ACKNOWLEDGEMENTS}

This research was supported by the National Innovation Program for Competitiveness and Productivity (INNÓVATE PERÚ) of the Ministry of Production of Peru and by the Scientific Research Institute (IDIC) of the University of Lima.

\section{REFERENCES}

AGUIRRE-PE, J.; QUISCA, S. I.; PLACHCO, F. P. Tests and numerical one-dimensional modelling of a high-viscosity fluid dam-break wave. Journal of Hydraulic Research, $v$. 33, n. 1, p. 17-25, 1995. https://doi.org/10.1080/00221689509498681

BARTELT, P.; BUEHLER, Y.; CHRISTEN, M.; DEUBELBEISS, Y.; GRAF, C.; MCARDELL, B.; SALZ, M.; SCHNEIDER, M. A numerical model for debris flow in research and practice. User Manual v1.5 Debris Flow. Switzerland: WSL Institute for Snow and Avalanche Research, 2013.

BARTELT, P.; BUEHLER, Y.; CHRISTEN, M.; DEUBELBEISS, Y.; GRAF, C.; MCARDELL, B.; SALZ, M.; SCHNEIDER, M. A numerical model for debris flow in research and practice. User Manual v.1.7 Debris Flow. Swtzerland: WSL Institute for Snow and Avalanche Research SLF, 2017.

BRUFAU, P.; GARCÍA-NAVARRO, P.; GHILARDI, P.; NATALE, L.; SAVI, F. 1D Mathematical modelling of debris flow. Journal of Hydraulic Research, v. 38, n. 6, p. 435-46, 2000. https://doi.org/10.1080/00221680009498297

CAMPBELL, R. H. Soil slips, debris flows and rainstorms in the Santa Monica Mountains and vicinity Southern California. Washington: USGS, 1975. 51 p.

CASTELLI, F.; FRENI, G.; LENTINI, V. Modelling of a debris flow event in the Enna area for hazard assessment. Procedia Engineering, v. 175, p. 287-292, 2017. https://doi.org/10.1016/j.proeng.2017.01.026

GARCIA, R.; LOPEZ, J. L. Debris flows on December 199 in Venezuela. In: JAKOB, M.; HUNGR, O. (ed.). Debris-flow Hazards and Related Phenomena. Berlin: Springer Verlag Praxis, 2005.

GERASIMOV, I. P.; ZVONKOVA, T. V. Natural hazards in the territory of the USSR: study, control and warning. In: WHITE, G. W. (ed.) Natural hazards: local, regional, global. Oxford: Oxford University Press, 1974. p 243-351.

HSU, S. M.; CHIOY, L. B.; LIN, G. F.; CHAO, C. H.; WEN, H. Y.; KU, C. Y. Applications of simulation technique on debris-flow hazard zone delineation: a case study in Hualien County, Taiwan. Natural Hazards and Earth System Sciences, v. 10, p. 535-545, 2010. https://doi.org/10.5194/nhess-10-535-2010

HUNGR, O. A model for the runout analysis of rapid flow slides, debris flows, and avalanches. Canadian Geotechnical Journal, v. 32, p. 610-623, 1995. https://doi.org/10.1139/t95063

HUNGR, O.; MCDOUGALL, S. Two numerical models for landslide dynamic analysis. $\begin{array}{llllllll}\text { Computers \& Geosciences, } & \text { v. 35, n. 5, p. 978-992, } 2009 .\end{array}$ https://doi.org/10.1016/j.cageo.2007.12.003 
INDECI. Reporte Complementario 01, de fecha 09 febrero 2019, TACNA - Jorge Basadre - Ilabaya (Mirave): Huaico. 2019. Available at: https://www.indeci.gob.pe/emergencias/tacna-jorge-basadre-ilabaya-mirave-huaicoreporte-complementario-01/. Access: out. 2019.

LAIGLE, D.; COUSSOT, P. Numerical Modeling of Mudflows. Journal of Hydraulic Engineering, v. 123, n. 7, p. 617-23, 1997. https://doi.org/10.1061/(ASCE)07339429(1997)123:7(617)

LI, T. Mountain hazards in China. In: OWENS, P. N.; SLAYMAKER, O. (eds.). Mountain geomorphology. London: Arnold, 2004. p. 219-241.

MILANESI, L.; PILOTTI, M.; CLERECI, A.; GAVRILOVIC, Z. Application of an improved version of the erosion potential method in alpine areas. Italian Journal of Engineering $\begin{array}{lllllll}\text { Geology and } & \text { Environment, v. } 1, \quad \text { p. } & 17-30,\end{array}$ https://dx.doi.org/10.4408/IJEGE.2015-01.O-02

MIZUYAMA, T. Structural countermeasures for debris flow disasters. International Journal of Erosion Control Engineering, v. 1, n. 2, p. 38-43, 2008. https://doi.org/10.13101/ijece.1.38

MIZUYAMA, T.; EGASHIRA, S. Sediment induced disasters in the world and 1999-Debris flow disasters in Venezuela. Journal of Disaster Research, v. 5, n. 3, p. 229-235, 2010.

MIZUYAMA, T.; KOBASHI, S.; OU, G. Prediction of debris flow peak discharge. In: INTERNATIONAL SYMPOSIUM INTERPRAEVENT, 1992, Bern, Switzerland. Proceedings [...] Bern: Interpraevent, 1992. p. 99-108.

O'BRIEN, J. S.; JULIEN, P. Y.; FULLERTON, W. T. Two-dimensional water flood and mudflow simulation. Journal of Hydraulic Engineering, v. 119, n. 2, p. 244-261, 1993. https://doi.org/10.1061/(ASCE)0733-9429(1993)119:2(244)

PHILLIPS, C. J.; DAVIES, T. R. H. Discussion of "Generalized Viscoplastic Modeling of Debris Flow" by Chen-lung Chen (March, 1988, Vol. 114, No. 3). Journal of Hydraulic Engineering, v. 115, n. 8, p. 1160-1162, 1989. https://dx.doi.org/10.1061/(asce)07339429(1989)115:8(1160)

QUISCA, S. I. Reporte de Proyecto de Investigación $\mathbf{N}^{\circ}$ 083-CONCYTEC - Modelos Numéricos para la Predicción de Flujos de Huaycos y Aluviones. Lima: Consorcio Minero Horizonte S. A., 2002.

QUISCA, S. I. Estudio geodinámico y diseño de obras de estabilización de las cuencas Alpamarca, Canal Huayco y cuencas tributarias. Lima: Consorcio Minero Horizonte S. A., 2010. 94 p.

RICKENMANN, D. L. Empirical relationships for debris flows. Natural Hazards, v. 19, p. 47-77, 1999. https://doi.org/10.1023/A:1008064220727

SCHUSTER, R. L.; SALCEDO, D. A.; VALENZUELA, L. Overview of catastrophic landslides of South America in the twentieth century. In: EVANS, S. G.; DE GRAFF J. V. (eds.). Catastrophic landslides: effects, occurrence, and mechanisms. Reviews in engineering geology. Boulder: Geological Society of America, 2002. p. 1-34.

SHEN, P.; ZHANG, L.; CHEN, H.; FAN, R. EDDA 2.0: integrated simulation of debris flow initiation and dynamics considering two initiation mechanisms. Geoscientific Model Development, v. 11, p. 2841-2856, 2018. https://doi.org/10.5194/gmd-11-2841-2018 
SOKOLOV, D. L. Caudal del río (Teoría básica y métodos de cálculo). Leningrado: Editorial Hidrometeorología, 1968. 539 p.

TAKAHASHI, T. Debris Flow - IAHR Monograph Series. Rotterdam: Balkema Publishers, 1991. $165 \mathrm{p}$.

WU, Y. H.; LIU, K. F.; CHEN, Y. C. Comparison between FLO-2D and Debris-2D on the application of assessment of granular debris flow hazards with case study. Journal of Mountain Science, v. 10, n. 2, p. 293-304, 2013. https://doi.org/10.1007/s11629-0132511-1 